\title{
THE VALIDITY AND RELIABILITY OF INSTRUMENTS FOR MEASURING ELEMENTARY SCHOOL STUDENTS' EARLY MATHEMATICAL ABILITY
}

\author{
Aan Yuliyanto ${ }^{1}$, Turmudi ${ }^{2}$, Ernawulan Syaodih ${ }^{3}$, Dadan Rusdiana Saputra ${ }^{4}$, Arie \\ Dharmawan $^{5}$, and Cahya Karisma Pertiwi ${ }^{6}$ \\ ${ }^{1}$ Universitas Pendidikan Indonesia, Bandung, Indonesia. \\ aanyuliyanto@upi.edu \\ ${ }^{2}$ Universitas Pendidikan Indonesia, Bandung, Indonesia. \\ turmudi@upi.edu \\ ${ }^{3}$ Universitas Pendidikan Indonesia, Bandung, Indonesia. \\ ernawulansy@upi.edu \\ ${ }^{4}$ Benda 1 Elementary School, Indramayu, Indonesia \\ saputradadan690@gmail.com \\ ${ }^{5}$ Klender 06 Elementary School, Jakarta Timur, Indonesia \\ ariedharmawan007@gmail.com \\ ${ }^{6}$ Universitas Pendidikan Indonesia Purwakarta Campus, Purwakarta, Indonesia \\ cahyakarisma@upi.edu
}

\begin{abstract}
Teachers need to understand students' early mathematical abilities before continuing learning on the next topic to retain the knowledge. This study aims to produce appropriate and reliable instruments for quality research related to early mathematical abilities. This research implemented R\&D. The subjects were 113 sixth-grade students of the elementary school in Karawang. The instrument used was a test to measure early mathematical ability. Validity and reliability tests indicated that the five initial mathematical ability test items were considered valid, with $r_{\text {count }}>r_{\text {table }}$ and p-value $<0.05$. The Cronbach's Alpha value was 0.875 (above 0.8 or high reliability). Thus, the five items of the early mathematical ability instrument on the volume of cubes and rectangular prisms can be used for further research to measure the same variables accurately. The results are not significantly different for the same subject even though the time and place are different.
\end{abstract}

\section{ARTICLE INFORMATION}

Keywords

Early Mathematical Ability

Instruments

Cubes and Rectangular Prisms
Article History

Submitted Jan 22, 2021

Revised Sep 1, 2021

Accepted Oct 26, 2021

\section{Corresponding Author}

Aan Yuliyanto

Primary Education Study Program, School of Postgraduate Studies, Universitas Pendidikan Indonesia Jl. Dr. Setiabudhi N. 229 Bandung 40154

Email: aanyuliyanto@upi.edu

\section{How to Cite}

Yuliyanto, A, Turmudi, T., Syaodih, E., Saputra, D.R., Dharmawan, A., \& Pertiwi, C.K. (2021). The Validity and Reability of Instruments for Measuring Elementary School Students' Early Mathematical Ability. Kalamatika: Jurnal Pendidikan Matematika, 6(2), 127-142.

https://doi.org/10.22236/KALAMATIKA.vol6no2.2021pp127-142 


\section{INTRODUCTION}

Mathematics is taught to students to help them organize logical reasoning, display personalities, and use mathematics and mathematical reasoning in real-life situations (Soedjadi, 2004). Mathematics in schools has its own goals, often meaningless manipulation of numbers, while mathematics serves as a means to achieve other goals, gives meaning to calculations related to everyday life, as a useful context for concentration, and can support persistence (Galla, Esposito, \& Fiore, 2020; Rampal, 2003). This goal will be achieved if students' understanding of the previous topic is good. Prior understanding is very important for students and is a target for the learning process (Shabrina \& Sumiati, 2020).

However, mathematics teachers in elementary schools sometimes tend to convey material directly without paying attention to students' understanding of the previous material. This is evident in studies that found several obstacles faced by teachers. For example, when the teacher teaches thematic material in the fourth grade, the acquisition of students' knowledge competencies is not optimal; this can be proven by the competence of previous knowledge below the Minimum Criteria of Mastery Learning (Luh, Santiasih, Ganing, \& Sujana, 2016). Previous understanding will affect how a person is involved in the new understanding (Ardiyanti, 2016). Previous understanding can build and develop mathematical concepts learned from understanding (Fatqurhohman, 2016). Prior understanding can be used to be aware of situations and determine strategies through thinking (Salayan \& Ariswoyo, 2020).

In learning mathematics, students need a solid foundation to understand the previous material to reach the next level. For example, to understand the topic of the volume of cubes and rectangular prisms, students must understand previous topics or prerequisites, such as arithmetic operations, area, and perimeter of shapes, measurement of units of length and volume, story problems, and other prerequisite topics. The previous understanding is referred to as Early Mathematical Ability. Early Mathematics Ability is the student's ability to understand the prerequisite material (Yuliyanto \& Turmudi, 2020). Students who know previous materials could follow and do the next learning (Jamaan, Musnir, \& Syahrial, 2020; MacDonald \& Carmichael, 2018). Early mathematical abilities can affect stable characteristics, affecting mathematics achievement over time (Watts et al., 2017). Students' early mathematical abilities also affect students' mathematical dispositions (Noviana, Hadi, \& Handayani, 2020). Thus, early mathematical ability is a prerequisite ability to support mathematics learning in subsequent topics. 
Previous research related to Early Mathematical Ability stated that the Realistic Mathematics Education Approach not only improves mathematical literacy in eighth-grade junior high school students with high early mathematical abilities, but also students with low early mathematical abilities on statistics topics (Sutisna, Budi, \& Noornia, 2018). Regarding the interaction of early mathematical abilities with learning, it was found that there was no interaction between learning and Early Mathematical Ability in improving the reasoning abilities of eighth-grade junior high school students (Ayal, Kusuma, Subandar, \& Dahlan, 2016). Through qualitative research, the development of students' early math abilities could be handled well by not only focusing on early math concepts at home but also by focusing on developing learning behaviors, such as engagement, resilience, curiosity, and challenge seeking (Kritzer, 2012). The parental reports about the amount of children's activity at home predicted the children's performance on standardized early math ability tests (Blevins-Knabe \& Musun-Miller, 1996). The problem-based learning approach had a significant effect on the critical thinking skills of high school students in terms of school level and early mathematics abilities (Widyatiningtyas, Kusumah, Sumarmo, \& Sabandar, 2015).

Previous studies above have revealed that early mathematical abilities have been examined quantitatively and qualitatively for junior high school and high school students. It also has been examined based on the parents and related statistics. However, instruments for measuring students' early mathematical abilities, especially in elementary schools, are limited. Therefore, this research revealed an instrument to measure the early mathematical ability of fifth-grade elementary school students on the topic of cubes and rectangular prism using the R\&D research method.

A tool is needed to measure students' early mathematical abilities appropriately to conduct research or learning mathematics by reviewing students' early mathematical abilities before proceeding to the next topic. Thus, it can be used to determine the students' previous understanding of the topic being taught. That is because to produce high-quality research; reliable instruments are needed (Putri, Wahyudy, Yuliyanto, \& Nuraeni, 2020). An assessment instrument is a tool used to make an assessment or evaluation, an instrument can be a test or non-test, and observation can be carried out in two ways, namely systematic and non-systematic observation. (Rafianti, Anriani, \& Iskandar, 2018). The Good instruments meet certain rules, provide accurate data according to their function, and only measure samples of certain behaviors. The characteristics of a good evaluation instrument are valid, reliable, relevant, representative, practical, 
discriminatory, specific, and proportional (Siswantari \& Maretha, 2020). Furthermore, empirical validation is carried out through validity and reliability tests to ensure that they can measure the measured variables and produce similar results even though they are used repeatedly (Putri et al., 2020). The validation of the research instrument aims to measure whether the instrument made is per the measurement assessment by the validator (Setyansah, 2020).

Thus, a good instrument must have validity, namely the accuracy of an instrument in measuring the variable to be measured, and reliability, namely the instrument's stability in measuring the measured variable repeatedly, at different times and places with the same subject. Validity can identify and be useful in determining the management of education compared to tests based on theoretical frameworks and other perspectives (Scheuer, Herrmann, \& Bund, 2019). A valid instrument can estimate the effect of an unbiased treatment. However, at the same time, it is not possible to ensure that all the assumptions necessary for the validity of the instrument have been met. (Rassen, Brookhart, Glynn, Mittleman, \& Schneeweiss, 2009). Thus, the validity measurement must be executed through logical validity with expert considerations and empirical validity by testing on a predetermined sample that is not part of the sample to be studied, at least one level above it. Validity can be quantified using Pearson's product-moment correlation coefficient (r) (McNamara, Hudson, \& Taylor, 2010).

Meanwhile, reliability is measured by determining the Cronbach's Alpha value because this study will use an essay-formed test instrument. Cronbach's Alpha is suitable for instruments in the form of essays or questionnaires (Yusup, 2018). Reliability can be understood as the consistency of test measurements when the measuring procedure is repeated (Baumgartner, Oh, Chung, \& Hales, 2002; Scheuer et al., 2019). Reliable instruments will achieve the same conclusions when applied to the same subjects at different times (Fan, 2018). Thus, this research will produce an appropriate and reliable instrument to measure the early mathematical abilities of fifth-grade elementary school students on the topic of volume cubes and rectangular prisms through validity and reliability trial.

\section{METHOD}

This research employed the $R \& D$ method. $R \& D$ is a systematic process to develop, improve, and assess education programs and materials (Gall, Gall, \& Borg, 2010; Jackson, 2009). The design used was ADDIE (Analysis, Design, Development, Implementation, and 
Evaluation). The purpose of this study was to produce an accurate and reliable instrument for measuring the early mathematical abilities of fifth-grade elementary school students on the volume of cubes and rectangular prisms. This study was conducted because some teachers still pay less attention to the extent of students' early mathematical abilities and tend to directly continue the topics that must be taught to their students. At the same time, the early mathematical ability of students is necessary to be understood by teachers before continuing with more complex materials requiring fundamental concepts. Studies explained that early mathematical abilities can be in the information of concepts, principles, procedures, and facts that a person already has (Nismawati, Nindiasari, \& Mutaqin, 2019). Sixth-grade elementary school students in West Java were the population in this research. The samples were 113 elementary school students in Karawang Regency, West Java, selected by purposive sampling. The results of the development of this test instrument used to measure the early mathematical abilities of fifth-grade elementary school students. The topic developed was related to the volume of cubes and rectangular prisms, so students must understand prerequisite topics, including numerical count operations, calculating square roots, determining the area of a two-dimensional shape, measuring long units, and finally, problem-solving.

The scoring guidelines in this study were modified from Facione (1994), as presented in Table.

Table 1. Guidelines for Scoring Students' Early Mathematics Ability

\begin{tabular}{ll}
\hline Score & \multicolumn{1}{c}{ Criteria } \\
\hline 4 & The solution is explained in full, almost all instructions are followed, the presentation is logical according to mathematical \\
& concepts, and there are no drawing/calculation errors.
\end{tabular}

The development of instruments was carried out based on logical validity and empirical validity. In logical validity, by considering three math experts in elementary schools based on the accuracy according to the content studied, the accuracy of wording, and psychological constructs, a readability test was carried out on students. Furthermore, empirical validity is taken by testing it on students who are not research samples, specifically at least one level above it, i.e., students in six-grades elementary schools; this is because these students have been deemed to have mastered the topic be tested. Data analysis using SPSS 25. The validity decision is identified based on the value of the correlation coefficient $\left(\mathrm{r}_{\mathrm{xy}}\right)$ and reliability based on the value of Cronbach's Alpha. If the sign on the validity test $<0.05$ and $t_{\text {count }}$ is positive and $>r_{\text {table }}$, the instrument is considered 
valid (Mahendra, 2015). Meanwhile, if the value of Cronbach's Alpha> 0.70 then the instrument is accepted, while Cronbach's Alpha> 0.8, the reliability is very good (Wells, Russell, Haraoi, Bissonnette, \& Ware, 2011). The interpretation of validity and reliability is based on the criteria developed by Guilford (1956) in Table 2.

Table 2. Interpretation of Test Validity and Reliability of Instruments

\begin{tabular}{|c|c|c|c|}
\hline$r_{11}$ & Interpretation of Reliability & $r_{x y}$ & Interpretation of Validity \\
\hline 0.80 to 1.00 & Very High & 0.90 to 1.00 & Very high \\
\hline 0,60 to 0,80 & High & 0,70 to 0,90 & High \\
\hline 0,40 to 0,60 & Intermediate & 0,40 to 0,70 & Moderate \\
\hline 0,20 to 0,40 & Low & 0,20 to 0,40 & Low \\
\hline \multirow[t]{2}{*}{$<0.20$} & Very Low & 0.00 to 0.20 & Very Low \\
\hline & & $<0,00$ & Not Valid \\
\hline
\end{tabular}

\section{RESULTS AND DISCUSSION}

\section{Early Mathematical Ability}

It has been explained that the early mathematical ability is the prerequisite ability that students have for understanding the next topic. In this research, early mathematical abilities were developed to understand the prerequisite abilities of students to study the topic of volume cubes and rectangular prisms. The blueprint for the initial mathematical ability instrument produced is shown in Table 3.

Table 3. Blueprint early mathematical ability instrument

\begin{tabular}{|c|c|c|c|}
\hline Items & Indicator & Questions & $\begin{array}{l}\text { Level of } \\
\text { Difficulty }\end{array}$ \\
\hline 1 & $\begin{array}{l}\text { Doing arithmetic calculations in } \\
\text { numerical count operations }\end{array}$ & $8-6 \times 8: 10+2=\ldots$ & Easy \\
\hline 2 & Calculating the square root & $\sqrt{ } 225 \times\left({ }^{3} \sqrt{ } 1000-3^{3} \sqrt{125}\right)=\ldots$ & Moderate \\
\hline 3 & $\begin{array}{l}\text { Determining the area of a two- } \\
\text { dimensional }\end{array}$ & $\begin{array}{l}\text { Pay attention to the shape below. Calculate the area of the } \\
\text { three shapes! }\end{array}$ & Difficult \\
\hline 4 & $\begin{array}{l}\text { Calculating the measurement of } \\
\text { length units }\end{array}$ & $5,000 \mathrm{~cm}+15 \mathrm{~km} \times 5 \mathrm{dm}-8 \mathrm{dam}=\ldots \ldots . \mathrm{m}$ & Difficult \\
\hline 5 & Solve problem-solving problems & $\begin{array}{l}\text { Mr. Adi wants to make a terrace on the left and right of his } \\
\text { villa with a length of } 7 \text { meters and a width of } 5 \text { meters for the } \\
\text { left side terrace and the right-side terrace, the size of each } \\
\text { side is } 4 \text { meters. Then how wide are the two terraces? }\end{array}$ & Difficult \\
\hline
\end{tabular}


Students are required to understand several topics at the previous meeting developed in this research to understand the volume of cubes and rectangular prisms, such as in item 1 about doing arithmetic calculations in numerical count operations with problems $8-6 \times 8$ : $10+2=\ldots$ This problem will encourage students' abilities when performing volume calculation operations for cubes and rectangular prisms. Furthermore, in item 2 about calculating the square root with the problem $\sqrt{ } 225 \times\left({ }^{3} \sqrt{ } 1000-{ }^{3} \sqrt{ } 125\right)=\ldots$ This problem will help students when learning the operations to calculate squares and cubic on the volume of cubes and rectangular prisms. Furthermore, in item 3 about determining the area of a two-dimensional like the problem in Figure 1.

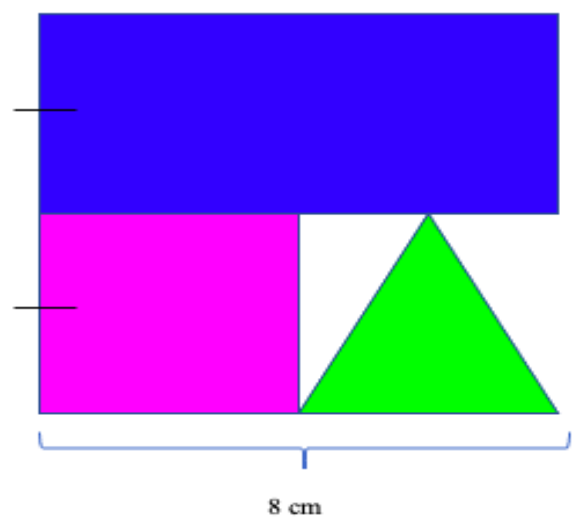

Figure 1. Problem Finding the Combined Area of the Construct.

Pay attention to the shape above. Calculate the area of the three shapes! In this problem, students are trained to discover the area of combined shapes; the questions will be useful for understanding the calculation of the volume of cubes and rectangular prisms combined. Furthermore, item 4 is about calculating the measurement of length units such as $15,000 \mathrm{~cm}+15 \mathrm{~km} \times 5 \mathrm{dm}-8 \mathrm{dam}=$ m. This problem will help students remember how to modify the unit of length, which will help students how to modify the volume unit. Furthermore, item 5 is about solving problem-solving problems such as the following questions: Mr. Adi wants to make a terrace on the left and right of his villa with a length of 7 meters and a width of 5 meters for the left side terrace and the right-side terrace, the size of each side is 4 meters. Then how wide are the two terraces? This question will train students on story problems in determining the volume of cubes and rectangular prisms, for example, in questions of determining the volume of bath water and dipping water. After the five instruments were developed, then the instrument validation was conducted. The validation of the research instrument aims to measure whether the instrument made is by the measurement assessment by the validator (Haryanti \& Saputro, 2016; Setyansah, 2020). 


\section{Validity Test Analysis}

The five items that have been constructed through logical validity are then tested for empirical validity. Following are the results of the validity trial presented in Table 4.

Table 4. Analysis of Early Mathematical Ability Validity Test

\begin{tabular}{llclrrr}
\hline Item & $\begin{array}{c}\text { Correlation } \\
\text { Value }\left(\mathrm{r}_{\text {count }}\right)\end{array}$ & $\begin{array}{c}\mathrm{r}_{\text {table }}(\alpha=5 \%, \mathrm{k}=\mathrm{n}- \\
2=111)\end{array}$ & $\begin{array}{l}\text { Direction of } \\
\text { Correlation }\end{array}$ & $\begin{array}{c}\mathrm{p}- \\
\text { value }\end{array}$ & Criteria & Conclusion \\
\hline 1 & 0.730 & & positive, $\mathrm{r}_{\text {count }}>\mathrm{r}_{\text {table }}$ & 0.000 & High & Valid \\
2 & 0.877 & 0.178 & positive, $\mathrm{r}_{\text {count }}>\mathrm{r}_{\text {table }}$ & 0.000 & Very High & Valid \\
3 & 0.871 & positive, $\mathrm{r}_{\text {count }}>\mathrm{r}_{\text {table }}$ & 0.000 & Very High & Valid \\
4 & 0.809 & & positive, $\mathrm{r}_{\text {count }}>\mathrm{r}_{\text {table }}$ & 0.000 & Very High & Valid \\
5 & 0.840 & positive, $\mathrm{r}_{\text {count }}>\mathrm{r}_{\text {table }}$ & 0.000 & Very High & Valid \\
\hline
\end{tabular}

Based on the results of the item validity test in table 4 , all items have a significant value with $\mathrm{p}$-value $<0.05$ and all $\mathrm{r}_{\text {count }}>0.178=\mathrm{r}_{\text {table }}$ and are positive so that all items are valid with the criteria item 1 is high, and others are very high in terms of the correlation coefficient according to (Guilford, 1956). The study said that the instrument is classified as valid if it has a positive and significant coefficient $<0.05$ (Muhsin, Slamet, \& Wahyudin, 2017; Yusof, Bahari, \& Adnan, 2014). It is also known that the lowest correlation value is 0.730. Meanwhile, the correlation coefficient $<0.3$ is low, $0.3-0.5$ is moderate, while $>0.5$ is high (Tsang, Royse, \& Terkawi, 2017). Instruments with a minimum correlation of 0.5 are considered capable of uncovering important and relevant issues to be observed (Masood, Masood, Saub, \& Newton, 2014). Thus, all items are considered to measure the early mathematical ability of the volume of cubes and rectangular with high accuracy.

\section{Reliability Test Analysis}

The analysis of the validity test indicates that the five items of the instrument are classified as valid and can measure correctly. To discover the instrument's stability in measuring the same subject, but at different times and places, a reliability test was carried out by determining the Cronbach's Alpha value. The summary of the instrument reliability test is listed in Table 5.

Table 5. Results of Early Mathematical Ability Instrument Reliability Tests

\begin{tabular}{lc}
\hline Cronbach's Alpha & N of Items \\
\hline 0.875 & 5 \\
\hline
\end{tabular}

Cronbach's Alpha value shows the instrument has very good stability. Research says that an instrument with a Cronbach's Alpha value> 0.70 can be concluded that all statements are reliable and can be used for further analysis (Astutik \& Priantono, 2020; Bolarinwa, 2015; Lima-Rodríguez, Lima-Serrano, \& Domínguez-Sánchez, 2015; Tsang et al., 2017). Because the instrument has excellent consistency, the instrument can be used to measure variables that are measured repeatedly with similar subjects even though the place 
and time are different.

\section{Face Validity}

Researchers in this study also investigated the advanced validity of the early mathematical ability instruments based on two experts in the field of mathematics education in elementary schools. The quality of the instrument is assessed based on three aspects such as the suitability of the instrument with the indicators, the suitability of the instrument with the material, and the readability of the instrument. Measurement of instrument quality using a scale between 1-5. The following is the results of the instrument quality assessment based on face validity in Table 6:

Table 6. Face Validity Results of Early Mathematics Ability Based on Expert Assessment

\begin{tabular}{llrl}
\hline No & \multicolumn{1}{c}{ Assessment Aspect } & Average & Criteria \\
\hline 1 & Suitability of the instrument with the indicators & 3.5 & Worth using/ testing with revision \\
2 & The suitability of the instrument with the material & 4.7 & Worth using/ testing with revision \\
3 & Instrument readability & 2.8 & Worth using/ testing with revision \\
& $\quad$ Total Average & 3.67 & Worth using/ testing with revision \\
\hline
\end{tabular}

Based on Table 6, the five items of the instrument, according to the experts, are considered suitable to be used to measure early mathematical abilities by requiring some improvements. The research revealed that the eligibility criteria for a product were observed based on a range of 1-5, namely 1.00-2.33 the product was considered unfit for use/tested, 2.34-3.67 the product was considered Eligible to be used/tested with revisions, and 3.68-5,00 products are deemed Eligible for use/ tested without revision (Arikunto, 2012). Reviewing the results of the instrument quality assessment according to the experts shows that the five items are considered good enough and deserve to be tested on the respondents to measure how well the students' early mathematical abilities are with a slight improvement before being tested. An in-depth assessment of an instrument must be carried out to find out how appropriate the measuring instrument is in measuring the aspects measured when used in the field. Supporting this, before implementation, the product developed was assessed for quality first by asking for an assessment from a team of experts (Wijayanti, Saputro, \& Nurhayati, 2015).

\section{CONCLUSION}

The development of early mathematical ability instruments related to the volume of cubes and rectangular prisms have been consulted with experts and tested on 113 fifthgrade elementary school students in Karawang. The validity and reliability test showed that the five items have good accuracy and reliability in measuring early mathematical abilities on the volume of cubes and rectangular prisms and can measure the same variables and 
subjects at different times and places in subsequent research. Early mathematical abilities are considered the foundation for students in studying the topics to be studied, so teachers are suggested to understand students' early mathematical abilities before continuing learning. To understand students' early mathematical abilities, teachers can use an instrument of a test with appropriate aspects and indicators as developed in this study.

\section{ACKNOWLEDGMENTS}

The researchers would like to thank the teachers and principals of Cikampek 2 Public Elementary School and the West Cikampek 3 Elementary School for allowing the researchers to develop instruments for early mathematical abilities on the topic of cubes and rectangular prisms for fifth-grade students.

\section{REFERENCES}

Ardiyanti, D. (2016). Kebudayaan Dan Perannya Dalam Pembentukan Moral Menurut Perspektif Konstruktivis. Jurnal Power in International Relations, 1(1), 37-50. https://doi.org/http://dx.doi.org/10.22303/pir.1.1.2016.37-50

Arikunto, S. (2012). Dasar-Dasar Evaluasi Pendidikan. Jakarta: Bumi Aksara.

Astutik, M., \& Priantono, S. (2020). Pengaruh Karakteristik Pekerjaan Terhadap Kinerja Karyawan dan Kepuasan Kerja Dengan Variabel Moderator Budaya Kerja Pada Badan Keswadayaan Masyarakat (BKM) di Kota Probolinggo. Jurnal Manajemen, 17(1), 81-97. https://doi.org/10.25170/jm.v17i1.1296

Ayal, C. S., Kusuma, Y. S., Subandar, J., \& Dahlan, J. . (2016). "The Enhancement of Mathematical Reasoning Ability of Junior High School Students by Applying Mind Mapping Strategy". Journal of Education and Practice, 7(25), 50-58.

Baumgartner, T. A., Oh, S., Chung, H., \& Hales, D. (2002). Objectivity, reliability, and validity for a revised push-up test protocol. Measurement in Physical Education and Exercise Science, 6(4), 225-242. https://doi.org/10.1207/S15327841MPEE0604_2

Blevins-Knabe, B., \& Musun-Miller, L. (1996). Number use at home by children and their parents and its relationship to early mathematical performance. Infant and Child Development, $\quad 5(1), \quad 35-45 . \quad$ https://doi.org/10.1002/(sici)10990917(199603)5:1<35::aid-edp113>3.0.co;2-0

Bolarinwa, O. A. (2015). Principles and Methods of Validity and Reliability Testing of Questionnaires Used in Social and Health Science Researches. Niger Postgrad Med, 
(22), 195-201.

Facione, P. A. (1994). Holistic Critical Thinking Scoring Rubric. Milbrae: The Califiornia Academic Press.

Fan, Y. (2018). Reflections on Practitioner Research: a Case Study in Efl Reading Instruction. European Journal of English Language Teaching, 3(3), 34-43. https://doi.org/10.5281/zenodo.1164402

Fatqurhohman. (2016). Representasi Matematis Dalam Membangun Pemahaman. Jurnal Math Educator Nusantara, 2(1), 43-54. https://doi.org/10.1017/CBO9781107415324.004

Gall, M. D., Gall, J. P., \& Borg, W. R. (2010). Applying Educational Research. New York: Pearson Education, Inc.

Galla, B. M., Esposito, M. V, \& Fiore, H. M. (2020). Mindfulness predicts academic diligence in the face of boredom. Learning and Individual Differences, 81, 101864. https://doi.org/https://doi.org/10.1016/j.lindif.2020.101864

Guilford, J. P. (1956). Fundamental Statistics in Psychology and Education. New York: McGraw-Hill.

Haryanti, F., \& Saputro, B. A. (2016). Pengembangan Modul Matematika Berbasis Discovery Learning Berbantuan Flipbook Maker Untuk Meningkatkan Kemampuan Pemahaman Konsep Siswa Pada Materi Segitiga. KALAMATIKA: Jurnal Pendidikan Matematika, 1(2), 147. https://doi.org/10.22236/kalamatika.vol1no2.2016pp147-161

Jackson, S. L. (2009). Research Methods and Statistics A Critical Thinking Approach (Third). Retrieved from www.ichapters.com

Jamaan, E. Z., Musnir, D. N., \& Syahrial, Z. (2020). The effect of problem-based learning model on students' geometry achievement by controlling mathematics initial ability. Journal of Physics: Conference Series, 1554(1). https://doi.org/10.1088/1742$6596 / 1554 / 1 / 012034$

Kritzer, K. L. (2012). The story of an outlier:... A case study of one young deaf child and his journey towards early mathematical competence. Deafness and Education International, 14(2), 69-77. https://doi.org/10.1179/1557069X11Y.0000000011

Lima-Rodríguez, J. S., Lima-Serrano, M., \& Domínguez-Sánchez, I. (2015). Psychometric 
properties of an instrument to measure family disease management. International Journal of Clinical and Health Psychology, 15(3), 253-264. https://doi.org/https://doi.org/10.1016/j.ijchp.2015.05.002

Luh, N., Santiasih, A., Ganing, N. N., \& Sujana, I. W. (2016). Penerapan Talking Stick dalam Pendekatan Saintifik untuk Meningkatkan Penguasaan Kompetensi Pengetahuan IPS dan Motivasi Belajar. MIMBAR PGSD Undiksha, 4(1), 10. https://doi.org/http://dx.doi.org/10.23887/jjpgsd.v4i1.7104

MacDonald, A., \& Carmichael, C. (2018). Early mathematical competencies and later achievement: insights from the Longitudinal Study of Australian Children. Mathematics Education Research Journal, 30(4), 429-444. https://doi.org/10.1007/s13394-017-0230-6

Mahendra, I. (2015). Analisa Penerimaan Pengguna Sistem Informasi Koperasi pada Koperasi Karyawan Budi Setia Jakarta dengan Technology Acceptance Model. Jurnal Pilar Nusa Mandiri, 11(1), 70-80. Retrieved from http://ejournal.nusamandiri.ac.id/index.php/pilar/article/view/415

Masood, M., Masood, Y., Saub, R., \& Newton, J. T. (2014). Need of minimal important difference for oral health-related quality of life measures. Journal of Public Health Dentistry, $\quad 74(1), \quad$ 13-20. $\quad$ https://doi.org/https://doi.org/10.1111/j.17527325.2012.00374.x

McNamara, E., Hudson, Z., \& Taylor, S. J. C. (2010). Measuring activity levels of young people: The validity of pedometers. British Medical Bulletin, 95(1), 121-137. https://doi.org/10.1093/bmb/ldq016

Muhsin, Slamet, A., \& Wahyudin, A. (2017). Educational Mixed Marketing Strategies and Sustainable Competitive Advantages in Mediating The Influence of Marketing Orientation Over Marketing. The Journal of Educational Development, 5(2), 153171. Retrieved from https://journal.unnes.ac.id/sju/index.php/jed/article/view/14299

Nismawati, N., Nindiasari, H., \& Mutaqin, A. (2019). Meningkatkan Kemampuan Berpikir Reflektif Matematis melalui Model Pembelajaran Problem Based Learning Berbasis Lingkungan. Jurnal Penelitian Dan Pembelajaran Matematika, 12(1), 78-93. https://doi.org/10.30870/jppm.v12i1.4856

Noviana, W., Hadi, W., \& Handayani, I. (2020). The Effectiveness of Geogebra-Based 
Van Hiele Model on Mathematical Disposition Assessed from Early Mathematics Ability. Kalamatika: Jurnal Pendidikan Matematika, 5(2), 167-180. https://doi.org/https://doi.org/10.22236/KALAMATIKA.vol5no2.2020pp167-180

Putri, H. E., Wahyudy, M. A., Yuliyanto, A., \& Nuraeni, F. (2020). Development of Instruments to Measure Mathematical Anxiety of Elementary School Students. International Journal of Learning, Teaching and Educational Research, 19(6), 282302. https://doi.org/10.26803/ijlter.19.6.17

Rafianti, I., Anriani, N., \& Iskandar, K. (2018). Pengembangan Perangkat Pembelajaran Matematika dalam Mendukung Kemampuan Abad 21. KALAMATIKA Jurnal $\begin{array}{lll}\text { Pendidikan } \quad \text { Matematika, } & \text { 3(2), }\end{array}$ https://doi.org/10.22236/KALAMATIKA.vol3no2.2018pp123-138

Rampal, A. (2003). Counting on everyday mathematics. Crosscultural Perspectives in Human Development: Theory, Research and Applications, 326-353.

Rassen, J. A., Brookhart, M. A., Glynn, R. J., Mittleman, M. A., \& Schneeweiss, S. (2009). Instrumental variables I: instrumental variables exploit natural variation in nonexperimental data to estimate causal relationships. Journal of Clinical Epidemiology, 62(12), 1226-1232. https://doi.org/https://doi.org/10.1016/j.jclinepi.2008.12.005

Salayan, M., \& Ariswoyo, S. (2020). Efektivitas Pembelajaran Matematika Menggunakan Model Pembelajaran CORE ( Connecting, Organizing, Reflecting, Extending ) Ditinjau Dari Disposisi Matematis Siswa. Edumaspul: Jurnal Pendidikan, 4(2), 5663. https://doi.org/https://doi.org/10.33487/edumaspul.v4i2.543

Scheuer, C., Herrmann, C., \& Bund, A. (2019). Motor tests for primary school aged children: A systematic review. Journal of Sports Sciences, 37(10), 1097-1112. https://doi.org/10.1080/02640414.2018.1544535

Setyansah, R. K. (2020). Development of Web-Based Learning Implementation and Android Applications to Bring Teacher Capability. Kalamatika: Jurnal Pendidikan Matematika, $5(2)$, $155-166$. https://doi.org/https://doi.org/10.22236/KALAMATIKA.vol5no2.2020pp155-166

Shabrina, N. M., \& Sumiati, N. (2020). Pendekatan Realistik terhadap Pemahaman Siswa pada Pembelajaran Matematika Sekolah Dasar. Didaktik: Jurnal Ilmiah PGSD STKIP 
Subang, 6(1), 112-119. https://doi.org/10.36989/didaktik.v6i1.118

Siswantari, H., \& Maretha, A. (2020). Evaluation Instruments of Dance Learning Outcomes Based on Theory of Multiple Intelligences in Elementary School. Journal of Teaching and Learning in Elementary Education (JTLEE), 3(2), 168. https://doi.org/10.33578/jtlee.v3i2.7851

Soedjadi, R. (2004). Designing Instruction of Values in School Mathematics. Proceedings of the Ninth International Congress on Mathematical Education, 195-196. https://doi.org/10.1007/978-94-010-9046-9_48

Sutisna, A. P., Budi, A. S., \& Noornia, A. (2018). The Influence of the Realistic Mathematics Education Approach and Early Mathematical Ability to Mathematical Literacy. International Journal of Multidisciplinary and Current Research, 6(4), 798801. https://doi.org/10.14741/ijmcr/v.6.4.18

Tsang, S., Royse, C. F., \& Terkawi, A. S. (2017). Guidelines for developing, translating, and validating a questionnaire in perioperative and pain medicine. Saudi Journal of Anaesthesia, 11(Suppl 1), S80-S89.https://doi.org/10.4103/sja.SJA_203_17

Watts, T. W., Clements, D. H., Sarama, J., Wolfe, C. B., Spitler, M. E., \& Bailey, D. H. (2017). Does Early Mathematics Intervention Change the Processes Underlying Children's Learning? Journal of Research on Educational Effectiveness, 10(1), 96115. https://doi.org/10.1080/19345747.2016.1204640

Wells, G. A., Russell, A. S., Haraoi, B., Bissonnette, R., \& Ware, C. F. (2011). Validity of Quality of Life Measurement Tools — From Generic to Disease-specific. The Journal of Rheumatology, 88, 2-6. https://doi.org/10.3899/jrheum.110906

Widyatiningtyas, R., Kusumah, Y. S., Sumarmo, U., \& Sabandar, J. (2015). The impact of problem-based learning approach tosenior high school students' mathematics critical thinking ability. Journal on Mathematics Education, 6(2), 30-38. https://doi.org/10.22342/jme.6.2.2165.107-116

Wijayanti, D., Saputro, S., \& Nurhayati, N. (2015). Pengembangan Media Lembar Kerja Siswa (LKS) Berbasis Hierarki Konsep Untuk Pembelajaran Kimia Kelas X Pokok Bahasan Pereaksi Pembatas. Jurnal Pendidikan Kimia Universitas Sebelas Maret, 4(2), 15-22. Retrieved from https://jurnal.fkip.uns.ac.id/index.php/kimia/article/view/5645 
Yuliyanto, A., \& Turmudi, T. (2020). Study Based on the Early Mathematical Ability of Elementary Student Self-efficacy through the Concrete-Pictorial-Abstract Approach. Universal Journal of Educational Research, 8(11B), 5901-5912. https://doi.org/10.13189/ujer.2020.082224

Yusof, D. M., Bahari, Z., \& Adnan, A. A. (2014). The Relationship between the Bank Choice Determinants and the Acceptance of Musharakah Mutanaqisah Home Financing among Malaysian Muslims. International Journal of Science Commerce and Humanities, 2(4), 130-145.

Yusup, F. (2018). Uji Validitas dan Reliabilitas Instrumen Penelitian Kuantitatif. Jurnal Tarbiyah: Jurnal Ilmiah Kependidikan, 7(1), 17-23. https://doi.org/10.18592/tarbiyah.v7i1.2100 
142 KALAMATIKA, Volume 6, No.2, November 2021, pages 127-142 